\title{
On the Political Economy of the European Union
}

\author{
Julia M. Puaschunder, ${ }^{1,2}$ Martin Gelter ${ }^{3}$ \\ ${ }^{1}$ The New School, Department of Economics, 6 East $16^{\text {th }}$ Street, 9 $9^{\text {rd }}$ floor 89, New York, NY 10003, US A, \\ Julia.Puaschunder@newschool.edu, T001212229 5700,F001212229 5724,www.juliampuascbunder.com \\ ${ }^{2}$ Columbia University, Graduate School of Arts and Sciences, Julia.Puaschunder@columbia.edu, bttp:/ / blogs.cuit.columbia.edu/jmp2265 \\ ${ }^{3}$ Fordham University School of Law and Center on European Union Law, 150 West 62 ${ }^{\text {nd }}$ Street, mgelter@law.fordham.edu
}

\begin{abstract}
Political economy concerns historical, legal and heterodox economics analysis of complex systems. This article attempts to analyze the current state of the European Union from historical, legal and interdisciplinary economics perspectives. Historically, the ancient Athenian democracy, the Holy Roman Empire and the early formation of the United States serve as examples of early innovative legal constructs of their times that were sui generis and share key features with the current European Union. Regarding legal developments, this paper discusses the bicameral parliamentary structure, electoral processes and populist pressures. The future of the European Union economy is likely to see an AI (r)evolution shaping markets and rising big data revenues. This develop necessitates the creation of a fifth fundamental freedom of data transfer within the European Union, as well as taxation of growth generated by big data. Heterodox economic growth theories will increasingly have to account for this growth.
\end{abstract}

KEYWORDS: Ancient Athenian democracy, Artificial Intelligence (AI), Bicameral parliament, Big data, Electoral system, European Union, Holy Roman empire, market disruption, political economy, Populist pressures, Taxation, United States

\section{Historical analysis}

\section{Ancient Athenian democracy}

The first known democracy developed around the fifth century BC in the Greek city-state of Athens, which featured the first government by its people. The supreme power was vested in the people and exercised directly by them or by their elected agents under a free electoral system. The ancient Athenian democracy became an important source for 18th-century revolutionaries' intellectual background during the American, French and other continental European revolutions. State constitutions around the globe and over time, political speeches and writings about nation states and society reflect the core principles conveyed in the ancient Athenian city state's democracy, which became a model shaping political structures around the world.

In $507 \mathrm{BC}$, the Athenian leader Cleisthenes introduced a system of political reforms called demokratia or rule by the people to ensure security, stability and prosperity to the entire community. Key features of modern democracy are equality, accountability, citizen participation, political tolerance, transparency, economic freedom and a multi-party political system. In the ancient Athenian democracy model, not every citizen had the right to vote, run for office and participate in political discussions. And yet, democracy was meant to protect and uphold the dignity of all people. Thereby the Athenian democracy bestowed a favorable climate in society without political equality of all citizens. To this day, democracy tends to generate the most advanced political order in an egalitarian society (Vlassopoulos 2009).

As a direct democracy, citizens voted directly on legislation and executive bills. However, participation in democracy was not open to all residents but limited to adult, male citizens excluding women, foreign residents and slaves. In ancient Athens, only male Athenian citizens who had completed their military training had the right to vote, and only about 10 to $20 \%$ of inhabitants actually participated in governmental decision-making. Women had limited rights and privileges, restricted movement in public and were legally segregated from men. Citizens whose rights were under suspension - foremost for failure to pay debts to the city - were also excluded from voting. Only descendants of both male and female Athenian parents could claim Athenian citizenship. Citizenship could also be granted by the assembly and was sometimes given to large population groups as a reward for service to the state. Slavery was widespread in Athens and seemed to have 
been a key factor for its development. The ancient Athenian democracy is therefore thought to economically having been based on slavery, which allowed the more privileged members of the public to devote considerable amounts of time to political life.

The Athenian form of direct democracy does not only serve as an example of not all citizens being allowed to vote being a feasible governmental structure. Athens also featured a dual system of the Athenian citizenry. Citizens from associated territories that were not allowed to participate in political decision-making but subject to accept conditions imposed on them. Both - full citizens and those from abroad from associated territories - lived together in one functioning society in the ancient Athenian world.

We may draw lessons from the ancient Athenian world for today's European Union, its member states and associated countries, but also for the exit of one of its member states. In order to avoid external conflicts, which in the end weakened ancient Athens and brought down the first attempts of a democratic state, the Europe Union should formally acknowledge the special relationship between the two parts of Europe - the European Union and other European countries. In ancient Athens there were different classes of citizenship that lived together. As in the ancient Athenian democracy model, in today's Europe, not every European has the right to vote in European Union elections. Today's European landscape faces a game-theoretically similar situation, with the more powerful countries' voting rights within the European Union determining the common external relations of the European Union. However, these decisions affect the economic and legal situation of all European countries implicitly. In the end, the outcomes of European Union votes affect the outcomes of all European citizens, some more directly and other more indirectly.

A future European Union may place Europe into a landscape in which some countries enjoy full voting powers, while other countries, which are on European soil or close to Europe, will have to abide by the laws crafted within the European Union compound but not have voting rights. These countries are, at present, Switzerland, Liechtenstein, Norway and Iceland, and to a certain extent countries with association agreements such as Ukraine and Georgia. In the future, the United Kingdom may find itself in a similar situation. These countries would be well-advised to form a union among themselves and should be granted the same treatment or rights by the European Union, which is currently not the case. At present, the treatment differs between countries, in part depending on whether it that refused to join the European Union, never applied to join, and whether the country chose to exit the European Union. Norway, Iceland and Liechtenstein are members of EFTA and the European Economic Area (EEA), while Switzerland is not a member after voting against joining in 1992. And yet, it participates in the internal market and the Schengen zone through several bilateral agreements. In the case of European Union grants and research funding, Switzerland and Israel are allowed to apply for research grants as associated countries; the United Kingdom was most recently prospected to lose the ability to apply for European Research Council grants. If the associated countries would be treated alike, there would be no retaliation on a caseby-case decision making basis. The European Union would also cut on administrative and organizational costs by creating a uniform legal framework determining how to deal with these countries. The EU should strive to consolidate negotiations and discussions into a 'League of Associated' so that European Union officials would not have to deal with each country separately administratively. Monitoring and streamlining the concerted fairness of the European Union towards its third countries will determine the geo-political relation of the European Union with its other European allies. Understanding the history of the ancient Athenian city empire being brought down by conflicts with peripheral countries underlines the case that living in harmony with third countries based on mutual respect and fairness will determine the future of the European Union and its European allies.

\section{Holy Roman Empire}

The European Union and its unwieldy federal system can also be compared to the Holy Roman Empire - a multi-ethnic complex of territories in Western and Central Europe that developed during the Early 
Middle Ages and continued until its end in 1806 during the Napoleonic Wars. The empire included large empires of the Kingdom of Germany, the Kingdom of Bohemia, the Kingdom of Burgundy and the Kingdom of Italy as well as hundreds of sub-units and smaller kingdoms, principalities, duchies, counties, prince-bishoprics, Free Imperial Cities and other domains (Johnson, 1996). The office of Holy Roman Emperor was traditionally elective, but remained in the hands of a small number of dynasties. The power of emperors was limited as for the de facto independence of individual territories within the entire Holy Roman Empire.

The Holy Roman Empire fell into decline during its later stages because it appeared outdated and administratively sclerotic in some ways. It still had a large number of small and heterogeneous political units that were prosperous for a long time, with only minimal central power though. The Holy Roman Empire did, however, provide some central features, such as imperial courts and an imperial army. Over the centuries, however, it shrunk in part because territories split off (e.g. Netherlands, Switzerland, Northern Italy), and because outside powers such as France continued to expand and annexed more and more of its territory. The havoc and destruction of the 30 Years War dealt a heavy blow, as the Westphalian Peace of 1648 expanded the sovereign status of its constituent parts. With the ascendance of nationalist ideology, it lost its legitimacy, thus allowing Napoleon to deal the final blow ending the Empire.

Drawing inference for today's European Union to maintain its position and its benefits, it must retain its legitimacy, both in fact and in perception. This means that it must perform the necessary functions for which it was designed, but not more. Consequently, it should not interfere with internal policies where it is not necessary for accomplishment of the common market, currency union and the freedoms. It should respect the principle of subsidiarity and allow some regulatory competition between the Member States. On the outside, it will have to provide some functions of a central government - especially in regards to trade policy, but also monetary and immigration policy, as well as external security. The monetary and immigration crises have undermined the credibility of the European Union in recent years because the European Union has not been capable of fulfilling these functions. In both cases, internal integration (of a currency union and a zone of free movement) cannot function without a considerable degree of centralization of policymaking and enforcement on the outside.

At the same time, the European Union has often been accused of overreaching on the inside as it arguably interfered with national policies too an excessive degree. This perception has bred economic conflicts, administrative hurdles and fueled exit sentiments. In other words, the European Union has been too weak in some areas and too strong in others. How can the European Union rebalance its activities to reclaim its legitimacy to effectively deal with the outside world again? This emerges as the salient question arising from Brexit. If the EU can reclaim its momentum, it should be able to stand the test of time internally and live in harmony with the League of Associated and even potential future exit candidates.

United States

Arguably, the European Union is in the process of transition from a supranational confederacy to a federal state system. We can learn about this evolution from the legal history of the formation of the United States in 1787. This historical example aids in understanding the currently ongoing European Union formation and integration endeavors (Kristoferitsch 2007). In the case of the United States formation, what first appeared to be a more economically-driven union led to a legal constitution and cultural integration. In the establishment of a constitution, the competencies between different state agencies was distributed differently and a common international affairs stance developed slowly. Military power bundling but also a stable federal judiciary were key in constituting a nation state. Voting systems evolved from state-level parliamentary votes and direct democracy action to a more detached indirect political establishment. Especially in light of constitutional powers and human rights, the European Union should envision tendency toward centralization.

In order to retrieve information on the European Union's capacity to regulate a large and nationally diverse territory while maintaining the nation states the ability to organize based on 
democratic principles, the formation of the United States under economic distress may aid in drawing inferences. In the formation of the United States, the First Great Depression of 1836-1848 had a profound effect on the structure of the government in the United States and the state governments. For most of American history until the Great Depression of the 1930s, the responsibilities and apparatus of the federal government were relatively limited compared to the powers of the states (Roberts 2012). Struggles in the American history during economic crises transformed into political and social upheaval such as the Civil War. During these times established political alliances were wrenched apart and matters of economic interest tinged with questions of honor and national pride (Roberts 2012). While we may learn from the past struggles of the US for the current European Union formation, one has to give credit to the speed of the European Union. Compared to the US, it has integrated faster, given that it still had its civil war ahead at the age of existence at which the European Union is currently.

Many of the lessons learned during the beginnings of the United States in regards to economic fragility hold invaluable insights on the current European Union identity formation, but also Brexit. Open economies, Roberts (2012) argues are intertwined with domestic and international politics. Historians report a crisis of trust among US states and citizens resulting in early attempts to secede, which can be compared to the current endeavor of Brexit. State debt became one of the hottest issues affecting the US international relations during the First Great Depression and caused frictions. These were eventually overcome in the case of defaulting nation state threats within the European compound, considering in particular Greece. As American and British observers said at the time, the struggle within state capitals raised a basic question about the balance of liberty and order, resulting in central government extensions in taxing, spending and regulating (Roberts 2012). All of these questions are more than relevant in today's post-Brexit European Union negotiations. While in the US history economic crises, default-prone states and the civil war led to a consolidation of taxation and federal unity in the end, the contemporary pressures to form an identity may also be vitalized by splitting with default-prone nation states. Federal law was established to hear cases involving disputes between a state and citizens of another state and between a state and foreign states, citizens, or subjects (Roberts 2012). The US Constitution Article III acknowledged that federal courts could hear disputes between two states or between a US and foreign state, while the Eleventh Amendment only precluded suits brought by citizens of other states or foreign states (Roberts 2012). The negotiation of these differences was difficult, often testing the union based on mutual trust and diplomacy. Similar factors will also determine the outcome of the European Union project. It required constant bargaining and the careful cultivation of good will in the case of the early US, which will also be required in the current European Union evolvement. Legislative pacts or mutual understandings will have to be consolidated in diplomacy on high level. It will be necessary to implement inequality alleviation strategies on a large scale such as forming a fiscal union to generate Euro-wide revenues - in the wake of territorial and commercial expansions of the European Union to breed social harmony and pro-European Union sentiments (Roberts 2012).

Roberts (2012) argues that there was a dissolution of trust throughout the American depressions, which may offer insights into the current post-Brexit sentiment. With the decline of trust, the vast and delicate web of commercial transactions collapses and economic activity halted. As the economy declines, however, the breakdown of trust becomes more general (Roberts 2012). Legislators and political executives stop trusting one another, which also freezes legislative compacts. In the case of the European Union and the segregationist stance of the United Kingdom, trust declines among nations and is displaced by rancor and antagonism in light of a falling currency and foreign direct investments spooked from the financial service sector oriented British economy. An initial problem of decaying commercial trust will inevitably degenerate into a broader and more difficult problem of decaying societal and inter-societal trust, which freezes economic activity - such as housing transactions on United Kingdom soil. Political institutions then have to strike the right balance between liberty and order. Public institutions will have to organize so that sovereignty and social order are preserved. The European Union may need a transformation in 
conventional wisdom about the role of government alongside institutional adaptations to restore order in the midst of economic, political, and social crisis of Brexit.

\section{Legal perspective}

\section{Bicameral parliament}

The European Union can already be described as having a legislative structure resembling a bicameral parliament: The national governments of the European Union (convening in the Council of the European Union) as the upper house, and the European Union Parliament as the lower house (Mandl 2019 in speech). Both are needed to legislate. Over the course of history, we generally see upper houses losing influence at the expense of lower houses - e.g. in the United Kingdom, but also the legislative structures in the late monarchies in countries such as Germany or Austria before World War I, compared to the modern republics where the lower house clearly takes precedence. In addition, we saw the United States Senate transitioning from a body whose members were delegated by the state legislatures to one with actual popular elections mandatory under the 17th Amendment since 1913, although it is still more powerful than the House of Representatives. Thus, legislative power resting in a popularly elected lower house seems to be characteristic of evolved democracies.

In the European Union, the Council still takes precedence. In the future, the European Union may prospectively go into the same direction - so that national governments as an upper house may lose influence relative to the European Parliament. Such a change would likely weaken the smaller Member States and impact the League of Associated. External negotiation partners have tapped into this current transition weakness of the European Union and invited national governments rather than the European Union Parliament to discuss trade and other economic agreements - e.g., Donald Trump but also the Chinese and Asian negotiators. This predicament of European Union or national governments as external allies that can eventually be pitted against each other has also been prevalent in international organizations such as the United Nations. To this day, the UN only acknowledges country votes but not the European Union voting as a united body. To solve this inner conflict and outside weakness of the European Union will likely determine a key source of credibility and economic power in the future of the European Union.

\section{Electoral system}

During the last European Union elections, the three main factions in the European Union Parliament were using a "Spitzenkandidaten" system, in which they promised to elect the leader of the largest party. In 2019, the liberal fraction defected from this model, apparently because President Macron, whose party constitutes many MEPs in the group, emphasizes the role of the Member States, particularly the leadership role of France. In the medium term, we may see the European Union take further steps towards a pan-European party system, and thus maybe a European Parliament that takes a more prominent role in the media and the minds of voters? With Brexit, it seems that one of the greatest obstacles on this - the royal United Kingdom - is leaving, yet the United Kingdom may still have a lasting influence on the European Union (Gelter 2017; Gelter \& Reif 2017).

\section{Populist pressures}

One might suspect that the European Union has long been able to produce good results for economic development and market integration because it was largely immune to populist pressures and therefore considered relatively stable. The two leading party families have controlled the European Commission and European Parliament for decades, with elections being largely irrelevant to governance. Thereby, the European government has been largely isolated from populist pressures. European citizens often appear somewhat ignorant and apathetic about the control of the European Parliament and its elections. Citizens do not seem to care or react to political movements on a European level, even if they go against their own economic and social interests. Not to mention Brexit, but a number of member states including Poland - the largest recipient of European funds - systematically behave in an anti-European 
manner. Many citizens remain inexplicably and deliberately extraneous to the process of forming political will by taking refuge in unproductive nationalist individualism.

One could say that the European Union supposed democratic deficit might actually be not a bug, but a benevolent feature if it comes to populist pressures. This may change with the ascendance of right-wing populist parties in the future but their entrance into the European Parliament stage appears somewhat slowed by the electoral system and the disparity of left and right wing representations within the European Union compound. Populist pressure, however, may attack the European Union from outside and bring about a fractionation of the entire system - if one considers the role of populist and demagogic tendencies during the Brexit vote.

\section{Economic perspective}

\section{Artificial Intelligence (AI) market disruption}

The entrance of Artificial Intelligence (AI) and the sharing economy into our contemporary markets, economies and society is believed to radically change the settings for companies, workers and investors. The introduction of AI in our contemporary society imposes historically unique challenges for humankind. The emerging autonomy of AI holds unique potentials of eternal life of robots, AI and algorithms alongside unprecedented economic superiority, data storage and computational advantages. Yet to this day, it remains unclear what impact AI and exponentially rising data transfer has on the workforce and economic growth. While globalization has been noted to have halted lately, AI-related industries are on the rise heralding a large-scale entrance of AI into our contemporary economy and society (Puaschunder 2019a, b, e, The Economist, January 24, 2019).

Technological development is bringing production and manufacturing closer to the end user in the sharing economy. The most obvious example is energy and a prospective attempt to decentralize renewable energy generation. Solar panel become more productive if energy need not be stored but simply can be shared with your neighbor when not needed it. Blockchain techniques used for decentralized energy grids are currently being tested, which could be used to share selfgenerated electricity. For instance, households could generate energy via rooftop solar panels not only for their own consumption but also to share energy among neighbors to overcome shortages and energy losses during storage. If such a decentralized energy grid takes off, renewable energy and sustainable consumption will change dependence on oil. Geopolitical implications would mean that the European Union becomes less dependent on oil reserves from third party territories.

There is also a projected impact of robotic development on international trade. With the ringing in AI revolution, technological development is bringing production and manufacturing closer to the end user. In the wake of the Fourth Industrial Revolution, robots are expected to become more efficient and affordable. With that, conventional globalization practices - such as offshoring manufacturing to cheap labor cost countries - will most likely decline. Reshoring will bring back production to where goods and services are actually and finally consumed. Robots are expected to be more accurate, can work 24/7, and less demanding than human workers. Millions of employees in the East may lose their jobs over the next few decades, substituted by robots in the West. In addition, advances in 3D printers may soon make it possible to substitute large factories with much smaller ones, closer to the consumer, where the manufacturing process is simplified thanks to the reproduction of models. A slowing of the traditional globalization feature of goods being shipped around the globe during production in global value chains and an overall reshoring trend are thereby expected to widen the gap between the rich and the poor. Globalized technology hubs are anticipated to grow economically, in which robotics, data and algorithms become new sources of productivity and revenue. In these futuristic hubs, even individuals who can afford a selfdriving car or robots will be able to accumulate capital as their devices and tools work for them. Imagine a robot serving your community or your self-driving car transporting passengers while you are asleep.Traditional industrial sites relying on cheap labor will likely experience a relative decline in productivity compared to AI-run technology hubs. In addition, not being able to afford and lacking the necessary skills to integrate robotics into the workforce productively may cause a 
decline in productivity. This may be coupled with reshoring trends of AI hubs employing robots that overtake traditional manual and repetitive tasks, which were previously outsourced to lowskilled labor countries. The gap between skilled and unskilled labor has never been as high as of now and this inequality is expected to grow with the ascent of robotics. Hence, the European Union would be well-advised to invest in new technologies - foremost robotics, AI and machine learning algorithms - and educate its population to integrate novel technologies into the contemporary European workforce and society (Puaschunder 2019b, f).

Future European economies must be prepared to measure the growth generated by AI and be foresighted about big data economic gains (Puaschunder 2016). Contemporary growth theories largely neglect these economic gains from AI and big data (Puaschunder 2019b). Economists are therefore advised to revising growth theories and integrating AI components into them (Puaschunder 2019b, e). The entrance of AI into economic markets should be modeled into the standard neoclassical growth theory - for instance by creating a novel index for representing growth in the artificial age comprised of GDP per capita and AI entrance measured by the proxy of Internet Access percent per country (Puaschunder 2019b). Such a futuristic outlook on the law and economics of AI entrance into our contemporary economies and society will facilitate a successful and humane introduction of AI into our world (Puaschunder 2019a).

\section{Data freedom}

Technological advances, including mobile phones and especially the internet, have contributed to globalization by connecting people all over the globe. The World Wide Web links billions of people and devices, providing innumerable opportunities for the exchange of goods, services, cultural products, knowledge, and ideas. The internet connectivity and volume of data crossing borders has risen exponentially in the last decade. The wealth of data provided about the single individual has never been as high as of now and is expected to continuously rise exponentially with the introduction of $5 \mathrm{G}$ technologies around the world (Puaschunder 2019b).

In an unprecedentedly interconnected world, the European Union is advised to push for domestic technology-enhanced production. While there are the four fundamental freedoms of the free movement of people, goods, services and capital, the European Union - to this day - does not have a standardized data freedom. Data is produced, generated and collected mainly on a national level. While high standards of privacy protection should be upheld for the sake of dignity in privacy, a fifth data freedom could help to share anonymized information freely within the European Union and building a European big data generating corporate world to harness data transfer deficits with the US and China. Without large data transfer pools, the European Union lacks the ability to produce big data storing companies and data provision monopolies, such as in the United States Google, Facebook, Instagram or Amazon, to name a few. The data deficit of the European Union to the United States and Asia - foremost China in Huawei but also the upcoming social credit rating - is enormous and not captured in standard neo-classical growth theories or economic accounting (Puaschunder 2019b). The European Union could therefore enhance its competitive edge by standardizing and fostering data exchange to bundle big data generating capacities within the European Union compound. A common data transfer rule within the European Union would also allow to gather and store data concertedly in order to derive well-informed inferences over trends and socio-economic needs of the European population. A possible way to enact an as such data freedom would be to enshrine Art. 1(3) of the General Data Protection Regulation (GDPR), which states "The free movement of personal data within the Union shall be neither restricted nor prohibited for reasons connected with the protection of natural persons with regard to the processing of personal data." into the Treaty on the Functioning of the European Union. The initial idea of a common defense could be revived in establishing a common data pool for collecting and storing information on a European Union-wide scale for security purposes. Bundling data power and allowing to derive inferences on a grand scale are predicted to be success factors of future digitalized economies dependent on data understanding and sharing capacities (Puaschunder 2019a). 


\section{Taxing AI activities and big data revenues}

Electronic outsourcing in the age of $\mathrm{AI}$ is likely to increase and with this trend a possible nudgital divide in the 21st century (Puaschunder 2017a, b, c). Future societies will derive economic growth from information sharing, which stands in direct contrast to privacy. Foremost established and codified in the GDPR and the Lisbon Treaty, human privacy is considered as an aspect of dignity that should be protected and upheld. Reaping of benefits of information shared by innocent citizens is thus to be regulated and monitored in the future (Puaschunder 2019a, c).

Future policies should address prescriptive recommendations how to educate individuals about the risks and dangers of information sharing in the digital age. It is important to pay attention to how to uphold accuracy in times of fake news and self-created social information. Certain societal segments that are not represented strongly online should somehow be integrated into big data in order to democratize the information, which is considered as big data 'norm,' or standard by which the social media user is measured on (Puaschunder 2016, 2018). At the same time, psychologically guided studies could unravel a predictive approach and validate the outlined ideas' validity by testing the proposed theoretical assumptions in laboratory and field study settings. In particular, the proposed nomenclature's validity could be studied and the percentage of information sharing types captured in the population. The moderator variable age could be phased in as it appears that younger people, who have more to lose given a longer time ahead to live are in particular prone to use new social media and lavishly share their lives in e-blasts to public.

Regarding direct state interventions and implications for the European Union, a data freedom would allow finding a concerted action on data transfer and the predicament between dignity in privacy and utility derived from information sharing (Puaschunder 2019a, c). A common agency that oversees data transfer - such as, for example, a prospective European Data Authority - would be in charge to determine monopoly powers within the IT sector to protect consumers. A more broad Corporate Social Responsibility view in the estimation of the benefits and harms of big data generating corporations is recommended. Splitting social media power cartels may be one solution to decrease the big data social media user disadvantage. Taxation of information transfer may create another incentive to slow down unreflected information share. Taxation of value generated via data transfer and data analytics may be used to offset problems of the costs and risks of social media privacy infringements or social stratification based on data in the big data era. In addition, fines for privacy infringement could help to uphold e-ethics in the digital age (Puaschunder 2019a, d).

The value of privacy must be measured to determine taxation schemes and fine control mechanisms. The privacy and information sharing predicament paradox may be scrutinized in behavioral economics laboratory and field experiments. For instance, laboratory experiments of behavioural insiders could measure how much money people would be willing to pay for repurchasing their data or having a social media account that can only be viewed but no personal data can be resold or put in context to others. Field experiments could be staged with data from online providers that offer stratified packages - online services that are offered for free in exchange of information or priced in exchange for privacy of the consumer. These attempts could also serve as a guideline for policy regulations and free market solutions. Social media could offer services of having accounts that are private in that sense that no surplus value can be reaped by reselling information or big data storage and computation can occur. This may serve as an indicator of revealed preferences of social media privacy. Potential individual influencing factors such as gender, age, trust and personality differences may be tested for in order to retrieve information on how to educate the social media user and regulate the social media provider.

\section{References}

Gelter, M. 2017. "EU law with the UK, EU law without the UK." Fordham International Law Journal 40: 1327-1334. Gelter, M. \& Reif, A.M. 2017. "What is dead may never die: The UK's influence on EU company law." Fordham International Law Journal 40: 1413-1442.

Johnson, L.R. 1996. Central Europe: Enemies, neighbors, friends. Oxford: Oxford University Press. 
Kristoferitsch, H. 2007. Vom Staatenbund zum Bundesstaat? Die Europäische Union im Vergleich mit den USA, Deutschland und der Schweiz. Wien: Springer.

Puaschunder, J.M. 2016. "Putty capital and clay labor: Differing European Union capital and labor freedom speeds in times of European migration." American Review of Political Economy 11(1): 96-120.

Puaschunder, J.M. 2017a. "Nudgital: Critique of a behavioral political economy." Archives of Business Research 5(9): 54-76.

Puaschunder, J.M. 2017b. „The nudging divide in the digital big data era.” International Journal of Research in Business, Economics and Management 4 (11-12): 49-53.

Puaschunder, J.M. 2018. „Nudging in the digital big data era.” European Journal of Economics, Law and Politics 4(4): $18-23$.

Puaschunder, J.M. 2019a. "Artificial Intelligence evolution: On the virtue of killing in the artificial age." Journal of Sociology 3(1): 10-29.

Puaschunder, J.M. 2019b. "Artificial Intelligence market disruption." Proceedings of the International RAIS Conference on Social Sciences and Humanities organized by Research Association for Interdisciplinary Studies (RAIS) at Johns Hopkins University, Montgomery County Campus, pp. 1-8, Rockville, MD, USA, June 10-11.

Puaschunder, J.M. 2019c. Big data, algorithms and health data. Report on behalf of the European Parliament, European Liberal Forum. Washington, D.C.: Library of Congress.

Puaschunder, J.M. 2019d. "Dignity and utility of privacy and information sharing in the digital big data age." International Journal of Commerce and Management Research 5(4): 62-70.

Puaschunder, J.M. 2019e. Revising growth theory in the artificial age: Putty and clay labor. Princeton University working paper retrieved at Social Science Research Network at https:/papers.ssrn.com/sol3/papers. cfm?abstract_id $=3385238$

Puaschunder, J.M. 2019f. On Artificial Intelligence's razor's edge: On the future of democracy and society in the artificial age." Scientia Moralitas: International Journal of Multidisciplinary Research 4 (1): 51-72.

Roberts, A.S. 2012. America's first great depression: Economic crisis and political disorder after the panic of 1837. Ithaca, NY: Cornell University Press.

The Economist, 2019. The steam has gone out of globalisation: A new pattern of world commerce is becoming clearer as are its costs. January 24. Retrieved at https://www.economist.com/leaders/2019/01/24/the-steam-has-goneout-of-globalisation

Vlassopoulos, K. 2009. Politics antiquity and its legacy. Oxford, UK: Oxford University Press. 